\title{
Research on Enhancement of the Competitiveness of Heilongjiang Agricultural Regional Economic Cooperation with Russia under the New System of Open Economy
}

\author{
Yanming $\mathrm{Hou}^{1,2, \mathrm{a}}$ and Zhen Guo ${ }^{1, \mathrm{~b}}$ \\ ${ }^{1}$ Harbin University of Commerce, China \\ ${ }^{2}$ HeiLongjiang Agricultural Engineering Vocational College, China \\ ahouyanming66@163.com, bguozhenhrb@163.com
}

\begin{abstract}
Keywords: Open economy; China and Russia; Agricultural regional economy; Cooperation competence
\end{abstract}

\begin{abstract}
The new system of open economy is reflected in the new system of "going out" Strategy and constructing a new mechanism for the sustainable development of foreign trade. Heilongjiang and Russia is witnessing the mature regional cooperation bases on the Eurasian Economic Union and China's One Belt and One Road Policy. But the strong economic and trade cooperation is still weak. Therefore, we need to deeply analyze how to solve the internal obstacles and the reasons for the formation of the external conflicts to explore the way to solve the problems. To find a effective measure to solve the problems is the way to Promote Sino Russian Regional Economic Cooperation competitiveness.
\end{abstract}

\section{Introduction}

Agricultural cooperation between China and Russia has become more and more attention with the deepening of cooperation between China and Russia and the implementation of the strategy of One Belt and One Road. The competitiveness of Sino-Russian agricultural regional economy cooperation is a new mode, new ideas and new bright spot under the background of the new economic system through the "gonging out" strategy. Heilongjiang agriculture in 2015 in Russia sown area has reached about 8000000 acres, more than 860 million kilograms of grain returned to transport, worth more than 100 million dollars.in 2016, Heilongjiang province is expected to develop into 8 million 500 thousand acres in Russia. It means that the Sino Russian cooperation in the field of Agriculture began to have the scale effect and enhance competitiveness under the new open economy system.

\section{New open Economy System}

Opening up to the outside world is the basic state policy of our country since the third Plenary Session of the 11th CPC Central Committee. To promote reform and innovation, and promote the development has been an important experience to achieve success for China's socialist construction in the past 30 years. In recent years, China's open economic development faces profound changes in the environment at home and abroad, The task of domestic reform and development is more arduous, International competition is increasingly fierce, the domestic economic development into the new normal. In the fifth Plenary Session of the 18th CPC Central Committee the party profoundly analysis environment at home and abroad, further affirmed the role of opening to the outside world in the new period of China's economic development, and the party lists the opening up policy as one of the five development of the concept during the" 13th Five-Year "period as well as the parity points out that "Adhere to open and development, we must conform to the trend of China's economic integration into the world economy, pursue mutual benefit and win-win opening-up strategy, develop a higher level of open economy".

The Connotation of New Open Economy System. Zhong Shan explained the new system of open economy from three aspects .First, from the view of the negative list and accessing to the 
national treatment as the starting point, Including the reform of the use of foreign investment, foreign investment management system in two aspects; Second, from the view of insisting on developing the multilateral cooperation and free trade zone together to Promote the improvement of the global trade management system ,China will actively participate in global economic governance, promote the group of 20 countries to Play the role of the main platform of global economic governance, promote the Doha round of the world trade organization by the multilateral trading system and actively participate in international cooperation on climate change, energy, resources security, food security and other global issues. At the same time china will speed up the implementation of the FTA Strategy, Positively develop the free trade relations with other countries and regions; Third, we will expand the opening up of the inland and the border to build a new system of all-round opening. China's opening to the outside world is from east to west, Eastern region is early to open up and see a rapid development. However, the central and western regions are generally lagging behind. China should open up to the outside world in the central and Western Regions, accelerate the pace of open border, construct the Silk Road Economic Zone, the maritime Silk Road to promote the policy of communication, border regions and neighboring countries connected, trade flow, the circulation of money and the people to enhance the level of opening the border.

The Understanding of New System of Open Economy Compared with the Original Open Economy. From "taking the advantage of powers" to "seeking potential". With the growth of the economy and the promotion of the status of the international, a country, especially a big country, will not always be the follower of international trend, but also will be the impact of the international environment and the changing. Compared with the past, The "13th Five-Year plan" puts forward a three new concept First, to promote the reform and improvement of the international economic governance system, and actively guide the global economic agenda, promote the international economic order in the direction of equality and justice, cooperation and win-win development. Second, we should promote actively the process of changing trade negotiations and to promote the formation of a fair. reasonable and transparent international economic and trade rules system. Third, we should accelerate the implementation of the free trade zone strategy, committed to the formation of a global high standard free trade area network; from "seeking benefit" to "common destiny". Continuously improve the quality and efficiency of the opening up of the country is one of the important principles and policies of our country to carry out international cooperation in the long term. But under the new normal, the opening up of China continues to expand the scale, to participate in the international production and circulation has deepened, and the major trading partners more closely, "The Belt and Road" proposed that countries along the major trade partners of the construction of shared interests and destiny. Russia is the largest partner of our country, and also the main neighboring country of Heilongjiang Province, The fortress of Sino Russian trade is Heilongjiang, So Heilongjiang has to bear the interconnection of infrastructure with major trading partner Russia to Promote staff interaction and production flow and bear the responsibility to Promote the industrial chain between China and Russia to form the integrated production network; from "expanding opening up" to "overall planning ". Considering the domestic situation and the international situation, in the international situation, it is important to find the development opportunities, to establish the foreign strategy from the domestic advantages, to emphasize the importance of the expansion of the open field and the depth. Expanding opening up is a national policy of our country, the process of economic development, opening up has made great progress, In the form of international economic integration situation, opening up to a certain extent will find overall cooperation mode inside and outside in "domestic and international" two markets and two resources, to enhance the level of competitiveness.

The Necessity of Heilongjiang's Regional Economic Cooperation with Russia under the New System of Open Economy. With the development of the economy, the Marginal Diminishing Effect of various factors in our country is obvious. Promoting economic growth and the low end of the market booming and the low end of the dividend and external advantages have been rapid released, it is difficult to continuously support the future of the new normal economic growth. 
Diamond theory tells us that a country should create and maintain the relative sustainable competitive advantages; we need to constantly explore new competitive advantages to promote the evolution of economy to a more reasonable structure and more complex forms of division of labor. The Fifth Plenary Session enriches the connotation of the optimization pattern of opening up to find ways to promote the development of economy under the new normal high dividend.

In the expected future, the external environment of China's economic development is still seeing the opportunity and challenge together. Among them, there are two obvious characteristics: First, the strategic space of international economic cooperation is upgrading, cooperation in the low-end industry is still expanding but the high-end portal has been gradually opened, cooperation in the field of high and new technology industry is becoming a new focus of cooperation in the world. Second, the integration of the regional economy and the construction of the multilateral trading system have become a new driving force for the international economic and trade cooperation. Different regions and different types of FTA construction are in the ascendant. Heilongjiang in this new situation should adapt to the new system of open economy, through cooperation to enhance the strength of international competition.

Constructing the new system of open economy, Accelerating the development of new advantages in international competition and cooperation, actively promoting the balance of domestic and external demand, import and export balance, the introduction of foreign capital and foreign investment balance, and gradually realize the basic balance of international payments, the formation of a new pattern of all-round opening. Adhere to the independent and open and open to the outside world, to strengthen the strategic plan, the implementation of a more active free trade area strategy, expand open economic development of new space. Heilongjiang to cultivate new agricultural competition advantage, by fostering foreign trade competitive advantage of Russian Regional Economic Cooperation in the new system of open economy, building a new open economy system of mutual benefit and win-win, multi balance, safe and efficient.

\section{The Problems of the Development of Heilongjiang and Russia}

Sino Russian Trade in Goods Is Not in Conformity with the Status of Big Powers. China's GDP ranks the second and Russia is ninth, Russia and china is not only a major economic powers, but also a foreign economic and trade countries, China and Russia have a common border line of 4291 kilometers, involving Heilongjiang, Inner Mongolia, Jilin and Xinjiang four provinces, obvious geographical advantages; At the same time, across Eurasia Russia has played a role in China trade with European countries "intermediary", in theory, there is a huge trade opportunities between China and Russia, but is not consistent with this, the bilateral trade volume and the economic power status and geographical advantages do not match. From table 1,we can read by the end of 2014 ,China for seven consecutive years is Russia's largest trading partner, but since 2004 the Russian foreign trade in Chinese has been hovering between $8 \sim 11$, the bilateral trade volume accounted for China's foreign trade turnover of around 2\%, in 2014, the Sino Russian trade volume of $\$ 88$ billion 400 million, it is still a big gap to $\$ 200$ billion between China and Russia .

Table 12004 -2014 Sino Russian economic and trade status changes

Unit: million dollars

\begin{tabular}{|c|c|c|c|c|c|c|c|c|c|}
\hline \multirow[b]{2}{*}{ year } & \multicolumn{3}{|c|}{$\begin{array}{l}\text { China Imports and exports } \\
\text { ranking in Russia }\end{array}$} & \multicolumn{3}{|c|}{$\begin{array}{l}\text { Russia Imports and exports } \\
\text { ranking in China }\end{array}$} & \multirow{2}{*}{$\begin{array}{l}\text { Bilateral } \\
\text { trade } \\
\text { volume }\end{array}$} & \multirow{2}{*}{$\begin{array}{l}\text { China's } \\
\text { total } \\
\text { trade } \\
\text { volume }\end{array}$} & \multirow{2}{*}{$\begin{array}{l}\text { The } \\
\text { proportion } \\
\text { of }(\%)\end{array}$} \\
\hline & exports & Imports & $\begin{array}{c}\text { Total } \\
\text { ranking }\end{array}$ & exports & Imports & $\begin{array}{l}\text { Total } \\
\text { ranking }\end{array}$ & & & \\
\hline 2004 & & & & 8 & 7 & 8 & 212.3 & 11547.9 & 1.8 \\
\hline 2005 & 4 & 3 & 2 & 8 & 8 & 8 & 291.0 & 14221.2 & 2.0 \\
\hline 2006 & 4 & 2 & 4 & 8 & 8 & 8 & 333.9 & 17606.9 & 1.9 \\
\hline 2007 & 4 & 2 & 2 & 7 & 8 & 8 & 481.7 & 21738.3 & 2.2 \\
\hline 2008 & 4 & 1 & 1 & 7 & 10 & 9 & 568.3 & 25616.3 & 2.2 \\
\hline
\end{tabular}


Table 1, cont.

\begin{tabular}{llllllllll}
\hline 2009 & 3 & 1 & 1 & 10 & 11 & 11 & 388.0 & 22072.2 & 1.8 \\
2010 & 6 & 1 & 1 & 9 & 10 & 11 & 554.5 & 29727.6 & 1.9 \\
2011 & 3 & 1 & 1 & 8 & 10 & 10 & 792.5 & 36420.6 & 2.2 \\
2012 & 4 & 2 & 1 & 8 & 10 & 9 & 881.6 & 38667.6 & 2.3 \\
2013 & 6 & 1 & 1 & & & 10 & 892.1 & 41603.3 & 2.1 \\
2014 & 2 & 1 & 1 & & & 9 & 884.0 & 43030.4 & 2.1 \\
\hline
\end{tabular}

Data sources: Ministry of commerce country report - Russia trade report $2005 \sim 2015$.

The Way of Sino Russian trade Mode Is Single. At present, the Sino Russian trade is still dominated by border trade, but the border trade is insufficient to the hinterland. province and Russia border line is 2981 kilometers long, accounting for $70 \%$ of Sino Russian border line ,The geographical position of Heilongjiang province and Russia has obvious geographical advantage In recent years, the trade with Russia, Heilongjiang province and Russia import and export value accounted for the province's total import and export $2 / 3$, accounted for nearly $1 / 4$ of the total import and export to russia, And Russia is the ten largest trading partner of Heilongjiang Province, the only remaining volume of trade to maintain the growth of the first major traditional trading partners. Therefore, the situation of the Russian border trade in Heilongjiang province can represent the situation of China's border trade with Russia. At present, Heilongjiang Province on the Russian trade is still the main border trade and general trade, processing trade is weak, not really deep into the hinterland of China and Russia, the hinterland of economic pull power shortage. As can read from the table 3, from 2006 to 2009, the Russian border trade proportion of Heilongjiang province accounted for half of the country, far higher than the general trade. Although since 2011, the general trade between Heilongjiang province and Russia rose rapidly, but the processing trade is still very weak, and slow growth, in 2012 the Russian trade processing of only $\$ 140$ million, and the Heilongjiang province and Russia geopolitical advantages and resources advantages is extremely inconsistent.

Table 2 From 2006 to 2012, Heilongjiang Province, Russia four categories of trade statistics Unit: Hundred million dollars

\begin{tabular}{|c|c|c|c|c|c|c|c|c|c|}
\hline \multirow[b]{2}{*}{ year } & \multicolumn{2}{|c|}{ General trade } & \multicolumn{2}{|c|}{$\begin{array}{l}\text { Small Border } \\
\text { trade }\end{array}$} & \multicolumn{2}{|c|}{$\begin{array}{l}\text { Improvement } \\
\text { trade }\end{array}$} & \multicolumn{2}{|c|}{ Other trade } & \multirow[b]{2}{*}{ Total } \\
\hline & $\begin{array}{l}\text { Total } \\
\text { import } \\
\text { and } \\
\text { export } \\
\text { volum } \\
\text { e }\end{array}$ & $\begin{array}{l}\text { The } \\
\text { propor } \\
\text { tion of } \\
(\%)\end{array}$ & $\begin{array}{c}\text { Total } \\
\text { import } \\
\text { and } \\
\text { export } \\
\text { volume }\end{array}$ & $\begin{array}{l}\text { The } \\
\text { propor } \\
\text { tion of } \\
(\%)\end{array}$ & $\begin{array}{c}\text { Total } \\
\text { impor } \\
\mathrm{t} \text { and } \\
\text { expor } \\
\mathrm{t} \\
\text { volu } \\
\text { me }\end{array}$ & $\begin{array}{l}\text { The } \\
\text { propo } \\
\text { rtion } \\
\text { of } \\
(\%)\end{array}$ & $\begin{array}{c}\text { Total } \\
\text { impor } \\
\mathrm{t} \text { and } \\
\text { export } \\
\text { volum } \\
\mathrm{e}\end{array}$ & $\begin{array}{l}\text { The } \\
\text { propor } \\
\text { tion of } \\
(\%)\end{array}$ & \\
\hline $\begin{array}{c}200 \\
6\end{array}$ & 11.3 & 16.92 & 46.4 & 69.46 & 0.5 & 0.75 & 8.6 & 12.87 & 66.8 \\
\hline $\begin{array}{c}200 \\
7\end{array}$ & 41.0 & 38.25 & 54.0 & 50.37 & 0.9 & 0.84 & 11.3 & 10.54 & $\begin{array}{c}107 . \\
2\end{array}$ \\
\hline $\begin{array}{c}200 \\
8\end{array}$ & 48.1 & 43.49 & 53.2 & 48.10 & 1.1 & 0.99 & 8.2 & 7.41 & $\begin{array}{c}110 . \\
6\end{array}$ \\
\hline $\begin{array}{c}200 \\
9\end{array}$ & 10.5 & 26.92 & 25.7 & 65.90 & 0.8 & 2.05 & 2.0 & 5.13 & 39.0 \\
\hline $\begin{array}{c}201 \\
1\end{array}$ & 117.2 & 62.14 & 64.4 & 34.15 & 1.2 & 0.64 & 5.8 & 3.08 & $\begin{array}{c}188 . \\
6\end{array}$ \\
\hline $\begin{array}{c}201 \\
2\end{array}$ & 122.8 & 58.28 & 78.1 & 37.07 & 1.4 & 0.66 & 8.4 & 3.99 & $\begin{array}{c}210 . \\
7\end{array}$ \\
\hline
\end{tabular}

Data source: Heilongjiang business Yearbook (2007 2013)。 
Sino Russian Mutual Investment Is Small and Concentrated in Specific Field. Between 2000 and 2013, Russia's direct investment in China accounted for below $0.2 \%$ of the total foreign investment. China's direct investment in Russia is significantly higher than the amount of Russia invests in China, but the proportion of total foreign investment in China is less than 3\%.Overall speaking, At present the subject of mutual investment between China and Russia is still mainly rely on the small and medium enterprises, investment mainly concentrated in low value-added, low technology trade, electronics, food, wood processing, agriculture and other fields, the lack of energy strategic cooperation on large projects and large companies to participate in. Although in recent years, some large enterprises in China and Russia began to participate in energy and infrastructure projects in the field of cooperation, but talk about a number of real plan implementation and implementation is not much. The main reason for this situation First, the two sides at the current level of economic cooperation in the field of economic cooperation in consultation and agreement stage, the real cooperation is mainly embodied in the energy sector; Second, Russia's domestic economic environment is not stable, the market is low maturity, poor implementation of the relevant system, the Chinese enterprises to enter the risk of a large; third, China and Russia want to cooperate in the field of cooperation in the field of differences, the Chinese side stressed the cooperation in the field of trade, finance, manufacturing and other areas of energy, but the Russian side is currently the major trading only in the energy industry; Fourth, Russia cooperation projects is lack of strength to promote, the project has a long time from the settlement to the completion ,they have the high cost of cooperative ,the risk is large. Put Russia-Tongjiang railway bridge project as an example, Although after the completion of the bridge, Tongjiang railway and the Russian Far East to Siberia railway is connected and open up a new transport channel Between the northeast of China and the Russian Far East ,yearly cargo capacity of 21 million tons The trade in goods between China and Russia is of great significance, But since March 2008 the project formally started after twists and turns, Only officially started the foundation in February 2014, but as of May 2015, the Chinese side has completed an investment of 950 million yuan, the completion of the total project $60 \%$, Russia has not yet started the news.

Table 3 From 2003 to 2013, the scale of mutual investment between China and Russia

Unit: hundred million dollars

\begin{tabular}{ccccccc}
\hline year & $\begin{array}{c}\text { The total } \\
\text { amount of FDI } \\
\text { of Chnia } \\
\text { absorbed from } \\
\text { Russia }\end{array}$ & $\begin{array}{c}\text { Total foreign } \\
\text { investment in } \\
\text { China }\end{array}$ & $\begin{array}{c}\text { The } \\
\text { proportion } \\
\text { of }(\%)\end{array}$ & $\begin{array}{c}\text { Net of Russia } \\
\text { FDI from } \\
\text { China }\end{array}$ & $\begin{array}{c}\text { Total foreign } \\
\text { investment of } \\
\text { China }\end{array}$ & $\begin{array}{c}\text { The } \\
\text { proportion } \\
\text { of }(\%)\end{array}$ \\
\hline 2003 & 0.54 & 535.05 & 0.10 & 0.31 & 285.47 & 0.11 \\
2004 & 1.26 & 606.30 & 0.20 & 0.77 & 549.80 & 0.14 \\
2005 & 0.82 & 603.25 & 0.14 & 2.03 & 122.61 & 1.66 \\
2006 & 0.67 & 630.21 & 0.11 & 4.52 & 176.34 & 2.56 \\
2007 & 0.52 & 747.68 & 0.07 & 4.78 & 265.06 & 1.80 \\
2008 & 0.60 & 923.95 & 0.06 & 3.95 & 559.07 & 0.71 \\
2009 & 0.32 & 900.32 & 0.04 & 3.48 & 565.29 & 0.62 \\
2010 & 0.34 & 1057.32 & 0.03 & 5.68 & 688.11 & 0.83 \\
2011 & 0.31 & 1160.10 & 0.03 & 7.16 & 746.54 & 0.96 \\
2012 & 0.30 & 1117.16 & 0.03 & 7.85 & 878.04 & 0.89 \\
2013 & 0.22 & 1175.86 & 0.02 & 10.22 & 1078.44 & 0.95 \\
\hline
\end{tabular}

Data source: China Statistical Yearbook (2004 2014)

The Soft Environment for Russia's Agricultural Cooperation Is Not Good. Russia's policy on foreign investment is uncertain, so that Heilongjiang's agricultural cooperation with Russia has been greatly affected. The Russian laws and regulations are not perfect, trade disorder, randomness strong policy and lack of transparency, official law enforcement is not standardized, and the wide 
range of taxes levied on the lack of uniform standards, strict use of chemical fertilizers, pesticides and agricultural pesticide residue standards, and so on, These problems lead to the legitimate rights and interests of enterprises and workers from Heilongjiang province are not effectively protected.

\section{The Measures to Promote Heilongjiang's Agricultural Regional Economic Cooperation and Competitiveness under the New System of Open Economy}

Construction of a New Two-Way Trade and Investment between the Open Economy and New System Improves the Integrated Production Network of the Internal and External Interaction of Heilongjiang and Russia. The development of new Open economy system needs to open the national door to engage in construction, based on domestic to full use of China's resources, market, system and other advantages, but also pay attention to the domestic and international economic linkage effect. The development of open economy needs to utilize the two markets and two kinds of resources to improve the competitive advantage of Heilongjiang province. To further co-ordinate the development of agricultural foreign trade and the adjustment of agricultural economic structure, and strive to improve the spillover effects of import and export trade. To carry out the deep processing of agricultural products to promote the processing trade, overall competitive advantage on the formation of Russian agriculture force of regional economic cooperation, combined with the "The Belt and Road" to expand the channels of competition.

To Adapt to the New Normal of the Russian Agricultural Introduction of Mixed Economy. According to the proposed reclamation the NO 1 document, "farms become into enterprises, reclamation areas become into the groups, diversified the equities", Heilongjiang overseas agricultural development takes the way of multiple introduction of partners to accelerate the development of mixed economy to form a three production linkage, two changes (industrialization and specialization), the pattern of development .Do cooperate in planting, leasing land, food processing, logistics and other aspects of the development of agricultural industrialization to link the capital chain and sales chain; Diversified cooperation, the formation of a cooperative company, the use of Chinese brands of agricultural machinery. Adhere to the combination of agriculture and animal husbandry oriented, according to the business principles to join in the shares but not hold the shares and have the dividend but not manage to digest the overseas planting ; introduce into Heilongjiang the mixed economic zone and to build the special agricultural processing park of the Russian free trade area, and realize the main producing areas and sales areas of direct docking to achieve competitiveness in regional economic cooperation in agriculture.

The New Mechanism of Agricultural Economic Cooperation between Russia and Heilongjiang under the New System of Open Economy. Heilongjiang in the open economy under the new system to open for the "open" strategy to create a favorable development space, Heilongjiang agriculture with its own open conditions, to achieve complementary advantages, dislocation competition, and safeguard the common interests. For a long time, Heilongjiang's agriculture has been restricted by the area of cultivated land and agricultural technology, and there has been a lack of growth. Under the framework of cooperation between China and Russia. Heilongjiang Land reclamation becomes a force engaged in planting in the Russian Far East. Based on the Russian Far East land development, it is expected in 2020 Heilongjiang land reclamation plan of overseas development reach 10 million farming acres. Meanwhile, Some farmers in Heilongjiang have been gradually developing a large scale agricultural planting in the Far East of Russia. The geographical position of Heilongjiang and the Russian agricultural economic cooperation region has continued to expand, together to form a joint force to compete,

The organization mode of "linkage effect" innovation of agricultural cooperative In the province of Heilongjiang and the Russian border port cities and hinterland city center organization composed of small and medium-sized enterprises, agricultural and industrial association of the Russian agricultural cooperatives, the formation of Heilongjiang and Russia jointly operate the new cooperation, mutual linkage. Truly realize the "agricultural cooperation mode government to promote enterprise market, farmers group management", so as to reduce operating costs, the government and the company risks, farmers benefit. In addition, enterprises in Heilongjiang 
province should be with Russia enterprises in equity and other ways to set up in the territory of the Russian Federation of agriculture and commerce, agricultural development, at the same time the province agricultural enterprises should cooperate with domestic enterprises, joint development of the Russian agricultural market development, production and marketing integration, gradually complete the unified land leasing, unified purchase of production materials, to promote the unity of trade reached. And in the long run, the two sides should reach a consensus to create a new company to complete the field of circulation in the field of efficient services, in order to reduce product costs, improve the international competitiveness of products.

The Establishment of the Russian New Agricultural Park to Carry out Specialized Agricultural Cooperation Mode. Relying on the natural advantages of agricultural development in Heilongjiang Province constructs the modern agricultural demonstration projects in the Far East. We should accelerate the construction of overseas agricultural park; change a single, low tech cooperation mode, from single agricultural planting to develop the deep processing of agricultural products, planting, breeding, processing and implementation of trade integration, to further expand cooperation areas and regions. Promoting the transfer of semi-finished processing and manufacturing industries in our province, promote the development of industrial agglomeration and linkage outside the territory of china. In order to achieve the upgrading of agricultural cooperation to combine elements of the two local advantages to promote the change from the "Chinese manufacturing" to "world manufacturing" and make a formation of a more powerful competitive advantage. Our province and Russia should break the regional thinking, break the border line, engage in strong cooperation and cooperation of the strength with the weakness to make the two sides of the national culture, local characteristics fully integrate into the agricultural park. Starting in the area of Russian Far East, we should encourage some large enterprises in the establishment of Heilongjiang Agricultural Par. At the same time, in the choice of Russia proper area lease some state farms builds the Heilongjiang village model, make full use of our advanced agricultural technology in agricultural science and technology cooperation and exchange, agricultural production and agricultural trade.

\section{References}

[1] C.H.Pei: The Basic Objectives and Main features of the New System of Open economy in China, Economics Trends ,2014, No.4. In Chinese.

[2] A.Y.Zhan: Constructing the New System of Open Economy, Macroeconomic management, 2016 , No.1. In Chinese.

[3] D.Wu: The Eevelopment Situation:Predicament and Reform Direction of Russian Agriculture, World Agriculture, 2016, No.11. In Chinese.

[4] J.Y.Li: On China and Russia Agriculture, Eurasian economy, 2015, No.7. In Chinese.

[5] X.Q.Guo: New Progress and Promotion Path of Economic and Trade Cooperation Between China and Russia, Eurasian Economy, 2014, No.5. In Chinese.

[6] Y.M.Li: Agricultural Trade Development Environment and Policy of China and India, World Agriculture, 2016, No7. In Chinese

[7] Y.F.Huang: Research on the Cooperation of Heilongjiang Province to Russia's Overseas Agricultural Development, Contemporary Rural Finance and Economics, 2014, No.12. In Chinese.

[8] U.L.Qiu: The Study of The Belt and Road Strategy and China Agricultural Internationalization, Chinese and Foreign Entrepreneurs, 2015, No.12. In Chinese.

[9] H.P.Chen: Longjiang Silk Road and Deepen the Research on Agricultural Cooperation with Russia, Siberian Studies, 2015, No.4. In Chinese.

[10]X.N.Liu: Give Full Play to the Geographical Advantage to Improve the Level of Opening up in Heilongjiang Province, Siberian Studies, 2013, No.3. In Chinese. 